\title{
ATOPIC ECZEMA DAN KOMORBIDITAS KONDISI PSIKOLOGIS: BAGAIMANA HUBUNGAN DAN TATALAKSANANYA
}

\author{
Ninda Nurkhalifah, Ridha Sasmitha Ajiningrum, Ilma Fahira Basyir, Genta Faesal \\ Atsani, Zanetha Mauly Ilawanda \\ Fakultas Kedokteran, Universitas Mataram, Indonesia. \\ Email: ninda.nurkhalifah07@gmail.com, ridhaajiningrum@gmail.com, \\ ilma.fakhira@gmail.com,gentafaesal16@gmail.com, zanethailawanda@gmail.com
}

\begin{abstract}
Abstrak
Eczema atopik atau dermatitis atopik (DA) adalah penyakit kulit yang bersifat inflamasi kronis yang berulang. Dermatitis atopik hampir 20\% terjadi pada anakanak dan $10 \%$ pada orang dewasa. Etiologi dermatitis atopik yaitu faktor genetik dan lingkungan yang menyebabkan kelainan pada epidermis dan sistem kekebalan tubuh. Tujuan penelitian ini untuk mengetahui komorbiditas psikologis pasien dermatitis atopic dan tatalaksananya. Metode penulisan artikel ini mencakup berbagai sumber yang berasal dari jurnal ilmiah di portal online publikasi jurnal seperti MedScape, Google Scholar, PubMed, dan NCBI, dengan kata kunci "Eczema Atopic" Hasil dari penelitian ini yaitu individu dengan DA berisiko mengalami gangguan psikologis. Komorbiditas psikiatri yang dapat terjadi pada pasien DA yaitu depresi, kecemasan, stres, gangguan perilaku dan psikosis. Dermatitis atopik memiliki dampak besar pada kesehatan mental dan kualitas hidup individu dengan DA akibat dari rasa gatal yang hebat, penyakit yang tidak dapat diprediksi dan perasaan cacat yang disebabkan oleh lesi kulit. Kesimpulan yang bisa ditarik yaitu individu dengan eksim atopik lebih mungkin mengalami depresi dan kecemasan karena efek gatal dan ketidaknyamanan, cacat, dan stigmatisasi sosial yang dirasakan. Kurang tidur akibat rasa gatal pada malam hari dapat meningkatkan resiko terjadinya gangguan jiwa. Hal tersebut menyebabkan individu dengan DA memiliki kualitas hidup yang lebih rendah dan tingkat stres yang lebih tinggi daripada individu yang sehat.
\end{abstract}

Kata kunci: Dermatitis Atopik; Eczema; Komorbiditas Psikologis; Kualitas Hidup

\section{Abstract}

Atopic eczema or atopic dermatitis $(A D)$ is a chronic recurrent inflammatory skin disease. Atopic dermatitis is almost $20 \%$ in children and $10 \%$ in adults. The etiology of atopic dermatitis is genetic and environmental factors that cause abnormalities in the epidermis and immune system. To determine the psychological comorbidities of atopic dermatitis patients and their management. The writing of this article includes various sources originating from scientific journals on online

\footnotetext{
Copyright holder: Ninda Nurkhalifah, Ridha Sasmitha Ajiningrum, Ilma Fahira Basyir, Genta Faesal Atsani, Zanetha Mauly Ilawanda (2022)

DOI $\quad: 10.54543 /$ fusion.v2i1.135

Published by : Rifa Institute
} 
Ninda Nurkhalifah, Ridha Sasmitha Ajiningrum, Ilma Fahira Basyir, Genta Faesal Atsani, Zanetha Mauly Ilawanda

portals of journal publications such as Medscape, Google Scholar, PubMed, and NCBI, with the keyword "Eczema Atopic" Individuals with AD are at risk for psychological disorders. Psychiatric comorbidities that can occur in AD patients are depression, anxiety, stress, behavioral disorders, and psychosis. Atopic dermatitis has a major impact on the mental health and quality of life of individuals with $A D$ as a result of intense itching, unpredictable disease, and feelings of disability caused by skin lesions. Individuals with atopic eczema are more likely to experience depression and anxiety because of the effects of itching and discomfort, disability, and perceived social stigmatization. Lack of sleep due to itching at night can increase the risk of mental disorders. This causes individuals with AD to have a lower quality of life and higher stress levels than healthy individuals.

Keywords: Atopic Dermatitis; Eczema; Psychological Comorbidities; Quality of Life

Diterima: 12-12-2021 Direvisi: 12-01-2022 Diterbitkan: 20-01-2022

\section{Pendahuluan}

Eczema atopik atau yang saat ini dikenal dengan dermatitis atopik (DA) adalah penyakit kulit yang bersifat inflamasi kronis yang berulang. Penyakit ini menyebabkan rasa gatal dan ketidaknyamanan yang hebat. Lesi gatal dan bekas luka akibat lesi mengakibatkan sulit tidur dan rasa malu secara sosial, sehingga mengganggu kualitas hidup penderita dan keluarga mereka. (Schonmann et al., 2020). Dermatitis atopik sering terjadi, hampir $20 \%$ terjadi pada anak-anak dan $10 \%$ pada orang dewasa di negara maju (Schonmann et al., 2020). Prevalensi di Amerika serikat sekitar 10\% sampai 17\% hampir mirip dengan yang ada di Eropa dan Asia (Yaghmaie, C. W. Koudelka and Simpson, 2013). Penyebab dematitis atopik tidak diketahui. Ada beberapa bukti bahwa faktor genetik dan mungkin sanitasi dan kebersihan lingkungan yang buruk dapat mempengaruhi terjadinya dermatitis atopik. Mengenai kecenderungan genetik, banyak pasien yang terkena dermatitis atopik memiliki keluarga dengan riwayat atopi, seperti asma, alergi makanan, dermatitis atopik sebelumnya, atau alergi serbuk bunga (Lifschitz, 2015b).

Gangguan kesehatan mental adalah salah satu penyebab utama kecacatan di seluruh dunia, dengan depresi dan kecemasan bersama-sama menyumbang lebih dari setengah beban itu. Depresi, bermanifestasi sebagai kehilangan minat dan kesenangan dalam hal-hal biasa dan pengalaman individu tersebut, depresi mempengaruhi sekitar 4,4\% dari populasi global. Gangguan kecemasan, ditandai dengan rasa takut yang berlebihan, kecemasan, atau penghindaran terhadap ancaman yang dirasakan dan mempengaruhi sekitar 3,6\% orang di seluruh dunia (Schonmann et al., 2020).

Baik depresi maupun kecemasan berhubungan dengan peningkatan morbiditas dan mortalitas. Eksim atopik telah terbukti dikaitkan dengan gangguan mental umum (depresi dan kecemasan) dan bunuh diri dalam studi cross-sectional yang telah dilakukan. individu dengan eksim atopik lebih mungkin mengalami depresi dan kecemasan karena efek gatal 
dan ketidaknyamanan, cacat, dan stigmatisasi sosial yang dirasakan Selain itu, kurang tidur akibat rasa gatal pada malam hari dapat meningkat resiko terjadinya gangguan jiwa (Schonmann et al., 2020).

Penelitian sebelumnya yang melaporkan hubungan antara $\mathrm{AD}$ dan komorbiditas psikiatri seperti depresi atau kecemasan pada pasien remaja dan dewasa dengan AD dan juga ditemukan gangguan terkait gangguan afektif, stres, gangguan perilaku dan psikosis (Kauppi et al., 2019b).

\section{Metode Penelitian}

Penulisan artikel ini mencakup berbagai sumber yang berasal dari jurnal ilmiah di portal online publikasi jurnal seperti MedScape, Google Scholar, PubMed, dan NCBI dengan kata kunci yang digunakan adalah "Eczema Atopic, Psychological Comorbidities, Quality of Life.

\section{Pembahasan}

\section{A. Definisi}

Dermatitis Atopik (DA) adalah penyakit kulit inflamasi yang umum, kronis, kambuhan, yang biasanya menyerang pada bayi (namun juga dapat terjadi pada masa dewasa). Atopi didefinisikan sebagai kecenderungan bawaan untuk menghasilkan antibodi imunoglobulin E (IgE) sebagai respons terhadap sejumlah kecil protein lingkungan umum seperti serbuk sari, tungau debu rumah, dan alergen makanan. Dermatitis berasal dari bahasa Yunani "derma" yang berarti kulit dan "itis" yang berarti peradangan (Thomsen, 2014). DA ditandai dengan adanya pruritus (rasa gatal di kulit), lesi eksim, xerosis (kulit kering), dan likenifikasi (penebalan kulit). DA sering kali merupakan penyakit pertama yang muncul dalam, "atopic march" (perkembangan sekuensial dari manifestasi penyakit atopi dari masa kanak-kanak), yang mengarah pada alergi makanan, asma dan/atau rinitis alergi pada sebagian besar pasien yang terkena (Kapur et al, 2018).

\section{B. Epidemiologi}

Dermatitis atopik terjadi sekitar 10\% hingga 30\% anak-anak dan $2 \%$ hingga $10 \%$ orang dewasa di negara maju. Prevalensi ini telah meningkat dua sampai tiga kali lipat dalam beberapa dekade terakhir. Pada studi yang dilakukan di Amerika Serikat menunjukkan bahwa prevalensi DA sekitar 10,7\% untuk anak-anak dan 7,2\% untuk orang dewasa. Onset penyakit biasanya muncul pada usia 5 tahun, dengan insiden tertinggi terjadi antara usia 3 dan 6 bulan, tetapi dapat terjadi pada semua usia (Avena-Woods, 2017). Sedangkan Cina dan Iran, tingkat prevalensi sekitar 2-3\%. (Brian , 2021). Dermatitis atopik memiliki insiden yang lebih tinggi di garis lintang yang lebih tinggi, hal ini mungkin terkait dengan penurunan paparan sinar matahari dan tingkat kelembaban yang lebih rendah. Dermatitis atopik dibagi menjadi tiga subset berdasarkan usia onset yaitu: (1) Dermatitis atopik awitan dini (lahir hingga 2 tahun); jenis dermatitis atopik yang paling 
Ninda Nurkhalifah, Ridha Sasmitha Ajiningrum, Ilma Fahira Basyir, Genta Faesal Atsani, Zanetha Mauly Ilawanda

umum, dengan sekitar $60 \%$ kasus dimulai pada usia 1 tahun. 60\% kasus sembuh pada usia 12 tahun, (2) Dermatitis atopik onset lambat; gejala dimulai setelah pubertas, dan (3) Dermatitis atopik onset senile; onset pada pasien dengan usia > 60 tahun (Kolb et al, 2020).

\section{Etiologi}

Dermatitis atopik memiliki etiologi yang kompleks yaitu faktor genetik dan lingkungan yang menyebabkan kelainan pada epidermis dan sistem kekebalan tubuh. Jika salah satu orang tua mengalami atopik, ada lebih dari 50\% kemungkinan keturunannya akan mengalami gejala atopik. Jika kedua orang tua terkena, sekitar $80 \%$ keturunan akan terpengaruh (Kolb et al, 2020).

Makanan, bahan kimia dan aeroallergen seperti serbuk sari, jamur, tungau dan bulu binatang juga berperan dalam patogenesis dan eksaserbasi dermatitis atopik pada $10 \%$ hingga $30 \%$ pasien. Pasien dengan DA rentan terhadap berbagai infeksi seperti S.aureus dan infeksi virus herpes simpleks yang dapat memperburuk keadaan pasien dermatitis atopic. Selain itu studi terbaru menunjukkan bahwa mungkin ada hubungan antara merokok dan onset AD pada dewasa (Brian, 2021).

\section{Kriteria Diagnosis}

Untuk mendiagnosis dermatitis atopik digunakan uji alergi yaitu uji tusuk (skin pricktest) dan pemeriksaan kadar IgE total sebagai kriteria diagnosis. Pada tahun 1980 Hanifin dan Rajka mengusulkan suatu kriteria diagnosis dermatitis atopik yaitu terdiri dari 4 kriteria mayor dan 26 kriteria minor (Evina, 2015).

Tabel 1. Kriteria Diagnostik Hanifin and Rajka

\begin{tabular}{cll}
\hline No. & \multicolumn{1}{c}{ Kriteria Minor } & \multicolumn{1}{c}{ Kriteria Mayor } \\
\hline 1 & Hiperpigmentasi & Pruritus (gatal) \\
\hline 2 & Tanda Dennie-Morgan & $\begin{array}{l}\text { Morfologi sesuai umur dan distribusi lesi } \\
\text { yang khas }\end{array}$ \\
\hline 3 & Keratokonus & Bersifat kronik eksaserbasi \\
\hline 4 & Konjungtivitis rekuren & Ada riwayat atopi individu atau keluarga \\
\hline 5 & Katarak subkapsuler anterior & \\
\hline 6 & Cheilitis pada bibir & \\
\hline 7 & White dermatographisme & \\
\hline 8 & Pitiriasis Alba & \\
\hline 9 & Fissura pre-aurikular & \\
\hline 10 & Dermatitis di lipatan leher anterior & \\
\hline 11 & Facial pallor & \\
\hline 12 & Hiperliniar palmaris & \\
\hline 13 & Keratosis palmaris & Papul perifokular hiperkeratosis \\
\hline 15 & Xerotic
\end{tabular}




\begin{tabular}{ll}
\hline 16 & Iktiosis pada kaki \\
\hline 17 & Eczema of the nipple \\
\hline 18 & Gatal bila berkeringat \\
\hline 19 & Awitan dini \\
\hline 20 & Peningkatan IgE serum \\
\hline 21 & Reaktivitas kulit tipe cepat (tipe 2) \\
\hline 22 & Kemudahan mendapat infeksi \\
& Stafilokokus dan Herpes Simpleks \\
\hline 23 & Intoleransi makanan tertentu \\
\hline 24 & $\begin{array}{l}\text { Intoleransi beberapa jenis bulu } \\
\text { binatang }\end{array}$ \\
\hline 25 & $\begin{array}{l}\text { Perjalanan penyakit dipengaruhi faktor } \\
\text { lingkungan dan emosi }\end{array}$ \\
\hline 26 & Tanda Hertoghe (kerontokan pada alis \\
bagian lateral)
\end{tabular}

Pada tahun 1980 Hanifin dan Rajka mengusulkan suatu kriteria diagnosis dermatitis atopik yaitu terdiri dari 4 kriteria mayor dan 26 kriteria minor. Diagnosis dermatitis atopik harus mempunyai 3 kriteria mayor dan 3 kriteria minor jika menggunakan kriteria Hanifin and Rajka. Kriteria ini cocok digunakan untuk diagnosis penelitian berbasis rumah sakit dan eksperimental.

William, dkk pada tahun 1994 memodifikasi dan menyederhanakan kriteria Hanifin and Rajka menjadi satu pedoman diagnosis dermatitis atopik yang dapat digunakan untuk diagnosis dengan cepat. Kriteria William, dkk yaitu:

1. Harus ada : Rasa gatal (pada anak-anak dengan bekas garukan).

2. Ditambah 3 atau lebih:

a. Terkena pada daerah lipatan siku, lutut, di depan mata kaki atau sekitar leher (termasuk pipi pada anak di bawah 10 tahun).

b. Anamnesis ada riwayat atopi seperti asma atau hay fever (ada riwayat penyakit atopi pada anak-anak).

c. Kulit kering secara menyeluruh pada tahun terakhir.

d. Ekzema pada lipatan (termasuk pipi, kening, badan luar pada anak <4 tahun).

e. Mulai terkena pada usia dibawah 2 tahun (tidak digunakan pada anak $<4$ tahun).

The Europian Task Force on Atopic Dermatitis membuat suatu indeks untuk menilai derajat dermatitis atopik, dikenal dengan istilah SCORAD (Score of atopic dermatitis). SCORAD dapat menilai derajat keparahan inflamasi dermatitis atopik dengan menilai (A) luas luka, (B) tanda-tanda inflamasi, dan (C) Keluhan gatal dan gangguan tidur. Tanda inflamasi yaitu eritema, indurasi, ekskoriasi, papul, dan likenifikasi. Eritema adalah 
Ninda Nurkhalifah, Ridha Sasmitha Ajiningrum, Ilma Fahira Basyir, Genta Faesal Atsani, Zanetha Mauly Ilawanda

kemerahan kulit karena pelebaran pembuluh-pembuluh darah. Indurasi adalah pengerasan, misalnya tentang jaringan (Evina, 2015).

\section{E. Komorbiditas Kondisi Psikologis}

Dermatitis atopik (DA) adalah penyakit inflamasi kronis yang dikaitkan dengan sejumlah komorbiditas gangguan psikososial. Individu dengan AD berisiko mengalami gangguan psikologis seperti stigmatisasi, diskriminasi, depresi, kecemasan, gangguan tidur dan ide bunuh diri yang akan berdampak negatif terhadap kualitas hidup (Oh et al., 2010; Kage and Treudler, 2020). Dermatitis atopik merupakan penyakit kronis jangka panjang yang dapat membebani pasien dan keluarganya sehingga berdampak serius pada kehidupan sehari-hari yang dapat mengakibatkan terjadinya komorbiditas psikiatri (Lifschitz, 2015a).

Kulit dan jiwa dilaporkan berkaitan dari perspektif embriologis, biologis, psikologis, dan budaya. Hubungan erat antara kulit dan jiwa ini telah lama dikenal dalam literatur ilmiah (Osman et al., 2011). Berikut ini merupakan hubungan antara kulit dan gangguan kesehatan mental yang diklasifikasikan menjadi empat kategori, yaitu:

1. Gangguan psikofisiologis: kategori ini mencakup kondisi kulit yang diperburuk oleh faktor psikologis dan stres, seperti psoriasis, dermatitis atopik, jerawat, urtikaria, pruritus, dan alopesia.

2. Gangguan psikiatri dengan gejala dermatologis: ini terutama merupakan kondisi psikiatri dengan gejala yang melibatkan kulit, seperti delusi parasitosis, trichitillomania, dermatitis artefacta, ekskoriasi neurotik, pruritus psikogenik, dan dismorfofobia.

3. Gangguan dermatologis dengan gejala psikiatri: dalam kategori ini, gejala/kondisi psikiatri adalah sekunder dari kondisi dermatologis; misalnya, alopecia areata, vitiligo, psoriasis umum dan neurofibroma;

4. Lain-lain: sindrom sensorik kulit, sindrom purpura psikogenik, penyakit pseudopsikodermatologi dan perilaku bunuh diri pasien dermatologi.

Komorbiditas psikiatri yang dapat terjadi pada pasien DA yaitu depresi, kecemasan, stres, gangguan perilaku dan psikosis. Penelitian di Jerman melaporkan bahwa terdpaat hubungan antara AD dan beberapa komorbiditas psikiatri. Ditemukan bahwa 34\% pasien dengan DA memiliki setidaknya satu diagnosis psikiatri (Kauppi et al., 2019a). Diantara semua diagnosis psikiatri pada pasien dengan DA, risiko depresi didapatkan paling tinggi. Individu dengan DA memiliki risiko tujuh kali lipat lebih besar mengalami depresi berat dan hampir enam kali lipat risiko lebih besar untuk gangguan depresi dibandingkan dengan individu yang yang tidak mengalami DA. Sebuah studi cross-sectional di AS juga mengungkapkan bahwa individu dengan DA secara signifikan lebih sering menunjukkan gejala depresi seperti kehilangan minat, keputusasaan, penurunan nafsu makan, kelelahan, dan penurunan kemampuan berkonsentrasi. Depresi tampaknya terkait dengan kehadiran sitokin proinflamasi, khususnya tumor nekrosis faktor (TNF)- $\alpha$, interleukin 6 dan CRP (Kauppi et al., 2019a; Kage and Treudler, 2020). 
Selain depresi, gangguan kecemasan juga dikaitkan dengan DA yang merupakan komorbiditas psikiatri yang paling umum. Indvidu dengan DA memiliki risiko dua kali lebih besar mengalami gangguan kecemasan dibandingkan individu yang tidak mengalami DA. Sebuah penelitian menunjukkan bahwa dermatitis atopik memiliki dampak besar pada kesehatan mental dan kualitas hidup individu dengan AD akibat dari rasa gatal yang hebat, penyakit yang tidak dapat diprediksi dan perasaan cacat yang disebabkan oleh lesi kulit (Osman et al., 2011). Selain depresi dan cemas, gangguan tidur juga dikaitkan dengan pasien DA karena dapat mengganggu kualitas hidup pasien (Schonmann and Mansfield, 2019; Kage and Treudler, 2020).

Gejala utama dermatitis atopik adalah pruritus atau rasa gatal yang dapat hilang timbul sepanjang hari, tetapi umumnya terasa lebih hebat pada malam hari. Sebuah penelitian melaporkan bahwa gejala yang paling terasa dan berpengaruh pada kualitas hidup pasien DA adalah rasa gatal. Karena rasa gatal tersebut pada penderita dengan luas lesi ringan sampai sedang dan berat pun dirasakan paling mengganggu ketika melakukan aktivitas sehari - hari (Kage and Treudler, 2020). Gejala yang ditimbulkan pada penderita dengan lesi berat mengenai seluruh aspek yaitu sosial, fisik dan psikologis. Semakin luas lesi dermatitis atopik, semakin berat pula gejala yang dirasakan penderita, sehingga penderita juga merasa terganggu dalam melakukan aktivitas sehari-hari dan dalam kehidupan sosialnya (Indrastiti, Kurniati and Saputri, 2016; Kage and Treudler, 2020).

Individu dengan DA telah terbukti memiliki kualitas hidup yang lebih rendah dan tingkat stres yang lebih tinggi daripada individu yang sehat. Kualitas hidup pasien DA menurun seiring dengan meningkatnya keparahan lesi (Kage and Treudler, 2020). Secara umum, kualitas hidup adalah konsep multidimensi yang mencakup penilaian diri terhadap kondisi fisik, kondisi mental (kecemasan, depresi, harga diri dan citra diri), situasi sosial (kepuasan dengan pekerjaan, penghasilan dan waktu luang), dan hubungan interpersonal (dukungan sosial dan interaksi dengan orang lain). Dampak pada kualitas hidup mencakup semua aspek emosional, sosial, dan fisik dari kehidupan individu yang dalam kasus pediatri, tidak hanya mempengaruhi pasien tetapi juga keluarga (Lifschitz, 2015a).

Kualitas hidup dapat dipengaruhi oleh kronisitas dan visibilitas lesi kulit, serta oleh kebutuhan pengobatan seumur hidup. Oleh karena itu, kondisi dermatologis dapat memengaruhi kualitas hidup pasien, baik secara subjektif maupun objektif. Dermatitis atopik yang terjadi pada anak-anak, efek kualitas hidup tidak hanya untuk pasien, tetapi juga untuk keluarga mereka. Misalnya, efek psikososial dari DA pada masa anak-anak termasuk gejala gatal dan nyeri dapat menyebabkan sulit tidur. Kurang tidur tersebut dapat menyebabkan kelelahan, perubahan suasana hati, dan gangguan fungsi psikososial anak dan keluarga, terutama di sekolah maupun di tempat kerja. Ibu dari bayi atau anak dengan dermatitis atopik menunjukkan perilaku emosional yang lebih negatif seperti depresi dan kecemasan (Osman et al., 2011). Pada anak-anak dan dari segala usia, rasa gatal bisa sangat hebat yang mengakibatkan tidak bisa tidur (Lifschitz, 2015a). Individu dengan DA 
Ninda Nurkhalifah, Ridha Sasmitha Ajiningrum, Ilma Fahira Basyir, Genta Faesal Atsani, Zanetha Mauly Ilawanda

menderita pruritus kronis atau intermiten dan dikaitkan dengan gangguan tidur dan stigmatisasi karena lesi kulit yang terlihat yang akan berdampak negatif pada kesejahteraan psikologis pasien. Individu dengan DA diduga mengalami peningkatan ide bunuh diri dan berpotensi untuk bunuh diri dan hal tersebut dapat memengaruhi kualitas hidup pasien (Yaghmaie, C. Koudelka and Simpson, 2013; Lifschitz, 2015a).

Mekanisme yang mendasari gangguan kesehatan mental dan DA tidak diketahui. Pruritus intens, gangguan tidur, stres emosional, stigma sosial dan peningkatan kadar sitokin yang umum terjadi pada kondisi dermatologis dan psikiatris umumnya diduga sebagai faktor predisposisi (Kauppi et al., 2019a). Pruritus pada DA dapat mengganggu kualitas tidur pada anak-anak dan orang dewasa, dengan kesulitan tidur dan sering terbangun di malam hari berkontribusi pada perkembangan depresi dan kecemasan (Thorsti, Rønnstad and Halling-overgaard, 2018). Pola tidur yang terganggu memiliki efek negatif pada keadaan mental anak-anak dan dewasa termasuk efek pada perilaku, perhatian, dan suasana hati. Sebuah penelitian melaporkan bahwa depresi, kecemasan, dan autisme yang terjadi pada individu dengan DA diakibatkan karena terjadi peningkatan kadar sitokin pro-inflamasi. Oleh karena itu, DA dan kondisi mental secara bersamaan dapat mengakibatkan gangguan di jalur inflamasi (Yaghmaie, C. Koudelka and Simpson, 2013; Schonmann and Mansfield, 2019). Pada dermatitis atopik terjadi peningkatan sitokin proinflamasi secara kronis yang melintasi sawar darah otak dan peristiwa ini telah dihipotesiskan sebagai faktor predisposisi terjadinya gangguan spektrum autisme, dan komorbiditas psikiatri lainnya pada pasien DA (Thorsti, Rønnstad and Halling-overgaard, 2018; Kauppi et al., 2019a).

Stigmatisasi sosial karena lesi kulit yang terlihat juga berpotensi berkontribusi pada komorbiditas penyakit psikiatri pasien DA. Berdasarkan penelitian didaptkan terdapat hubungan antara tingkat keparahan DA dan depresi atau kecemasan (Thorsti, Rønnstad and Halling-overgaard, 2018). Kombinasi antara pruritus, stres psikologis, isolasi sosial, depresi, dan kecemasan diduga menjadi lingkaran setan pada pasien DA. Pada tingkat lesi yang berat dapat menyebabkan ide bunuh diri, percobaan bunuh diri, dan bahkan bunuh diri total yang pada akhirnya akan mengganggu kualitas hidup pasien dengan DA (Indrastiti, Kurniati and Saputri, 2016; Thorsti, Rønnstad and Halling-overgaard, 2018).

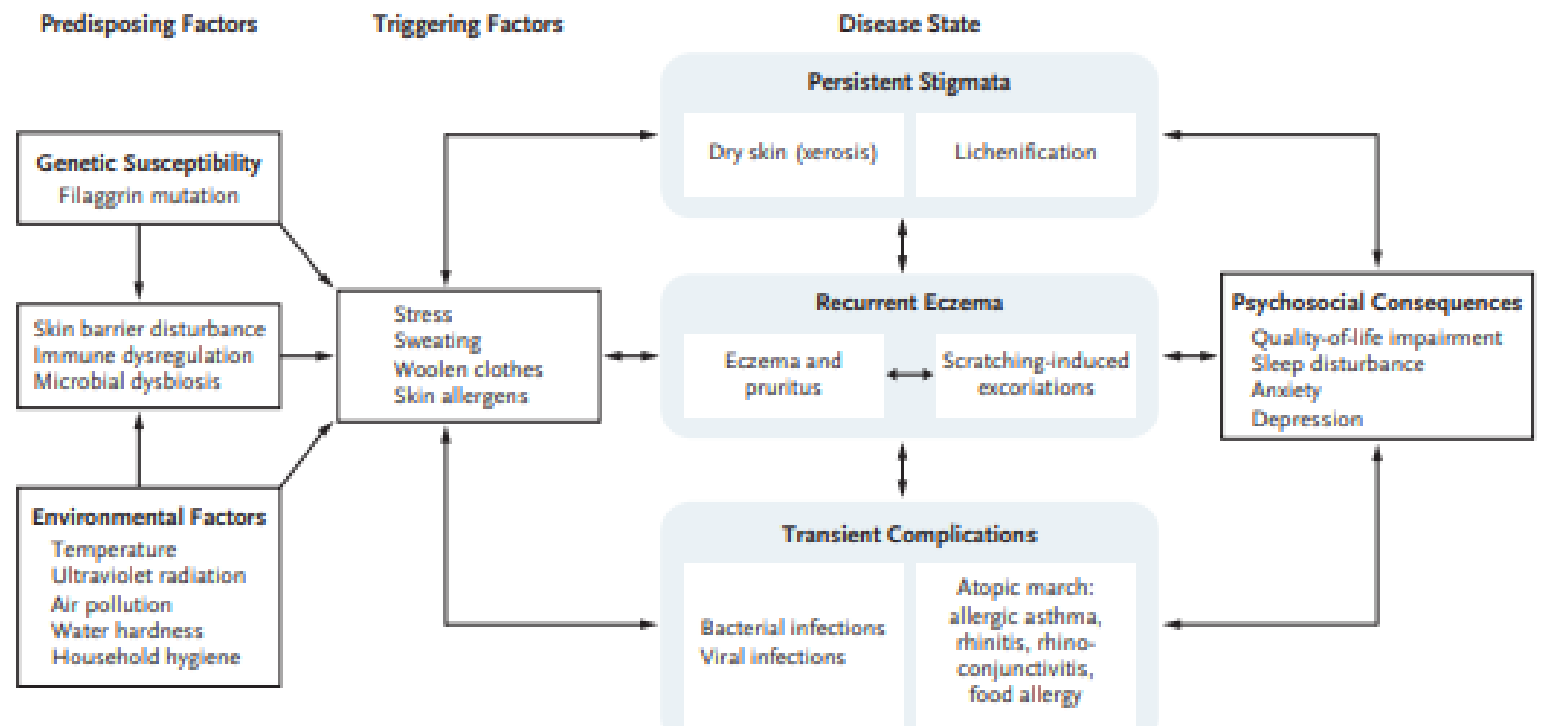


Atopic Eczema Dan Komorbiditas Kondisi Psikologis: Bagaimana Hubungan Dan

Tatalaksananya

Gambar 1. Faktor Predisposisi Dermatitis Atopik dan Konsekuensi Psikososial

Patogenesis DA didasarkan pada interaksi kompleks antara faktor predisposisi dan faktor pencetus. Faktor predisposisi yang berperan yaitu genetik karena terjadinya mutasi filaggrin, dan faktor lingkungan seperti suhu ekstrim, paparan radiasi ultraviolet, paparan polusi udara, kesadahan air, dan kebersihan rumah tangga. Hal tersebut akan menyebabkan terjadinya gangguan pada skin barrier/sawar kulit, disregulasi imun dan disbiosis mikroba. Gangguan pada sawar kulit ini dapat menyebabkan terjadinya stress, produksi keringat berlebihan, dan memudahkan alergen menembus kulit yang akan menginduksi sensitisasi alergi (Stander, 2021).

Stress yang terjadi akan merangsang sumbu hipotalamus-hipofisis-adrenal (HPA) untuk menginduksi pergeseran ke arah fenotipe sel T helper tipe 2 (Th2) untuk melepaskan neuropeptida $\mathrm{Y}$ dan neurotropin yang akan memengaruhi perkembangan dan perjalanan DA dengan menginduksi disfungsi penghalang epidermis dan menurunkan ambang gatal. Neuropeptida Y (NPY), neurotropin, substansi P (SP) dan faktor pertumbuhan saraf (NGF : Nerve Growth Factor) berfungsi sebagai penanda aktivitas penyakit pada pasien dengan DA. Neuropeptida dan neurotropin diakui sebagai mediator penting terkait dengan mekanisme gatal. NGF secara khusus dianggap sebagai salah satu mediator terpenting yang menurunkan ambang gatal. Ekspresi NGF di lesi epidermis DA dapat menginduksi aktivasi sel mast dan memperburuk rasa gatal. Selain itu, fibroblas dan sel inflamasi seperti sel mast, limfosit, dan eosinofil dapat melepaskan NGF. Kadar NPY yang rendah dalam plasma dan cairan serebrospinal telah ditemukan pada pasien dengan gangguan kecemasan. Tingkat NPY dalam plasma pasien dengan DA meningkat selama eksaserbasi penyakit dan lebih meningkat selama remisi. Kecemasan dapat meningkatkan ekspresi NGF dan melepaskan NPY dimana keduanya dapat berkontribusi pada pruritus atau rasa gatal. Dengan demikian, kecemasan mungkin terkait dengan induksi pruritus melalui NGF dan NPY (Benea et al., 2001; Oh et al., 2010).

Kondisi yang sebaliknya juga dapat terjadi jika pasien DA mengalami gangguan kecemasan dan depresi. Hal tersebut menjadi salah satu faktor predisposisi terjadinya DA sehingga menyebabkan keluhan dermatitis sering kambuh dan sukar untuk sembuh. Faktor psikososial termasuk stres dan keadaan emosional (misalnya, depresi dan kecemasan) juga memberi efek merusak pada berbagai kondisi medis termasuk kulit. Stres emosional dapat memperburuk banyak penyakit kulit kronis dan dapat memulai lingkaran setan yang disebut sebagai 'siklus gatal-garuk' (Oh et al., 2010; Osman et al., 2011). Mekanisme yang mendasari terjadinya peristiwa stres dapat memengaruhi penyakit kulit yaitu :

1. Terjadinya kelainan pada sumbu HPA (Hypothalamus-Pituitary-Adrenal)

2. Efek hormon steroid dan katekolamin pada sel imun

3. Faktor lokal (jaringan), seperti sekresi neuropeptida dan neurohormon dan perubahan fungsi sawar kulit. 
Ninda Nurkhalifah, Ridha Sasmitha Ajiningrum, Ilma Fahira Basyir, Genta Faesal Atsani, Zanetha Mauly Ilawanda

Pruritus yang terjadi pada dermatitis atopik didasarkan pada sinyal antara pruritogen yang dilepaskan oleh keratinosit, sel mast, sel imun, dan serabut saraf sensorik di kulit. Pruritogen terdiri dari sitokin Th2 (terutama interleukin-4, -13, dan -31), limfopoietin stroma timus (sitokin inflamasi proinflamasi yang diturunkan dari epitel), histamin, protease, dan neuropeptida. Pruritogen ini akan mengikat reseptor pada serabut saraf $\mathrm{C}$ sensorik di epidermis dan dermis sehingga menimbulkan gejala pruritus dan nyeri. Selain pruritus, keluhan yang diarasakan oleh pasien dengan dermatitis atopik yaitu sensasi nyeri, sensasi terbakar dan menyengat di daerah kulit yang mengalami ekzema. Pruritogen distimulasi tidak hanya oleh respon inflamasi saja, namun juga dari respon menggaruk yang akan mengakibatkan terjadinya hipersensitisasi serabut saraf karena siklus "gatal-garuk" (Stander, 2021).

Pruritus dan ekzema berulang yang terjadi akan menimbulkan beberapa komplikasi seperti infeksi bakteri, infeksi virus, asma, rhinitis alergi, dan respon alergi lainnya. Selain itu, akibat pruritus yang terjadi pada pasien DA dapat memengaruhi kondisi psikososial seperti penurunan kualitas hidup, gangguan tidur, cemas, dan depresi (Stander, 2021).

\section{F. Tatalaksana Umum dan Spesifik Kondisi Psikologis}

1. Psychological techniques using arousal reduction techniques

a. Relaksasi progresif

Teknik yang mengandalkan ketegangan otot yang berbeda di tubuh dan kemudian melepaskan ketegangan itu. Hal ini memungkinkan seorang individu untuk mengenali area ketegangan dan secara sadar belajar untuk melepaskan ketegangan itu.

b. Pelatihan autogenik

Bentuk relaksasi sistematis yang melibatkan peningkatan kesadaran tubuh.

c. Gambaran terpandu atau 'visualisasi'

Belajar menggunakan perumpamaan yang terkait dengan relaksasi atau ketenangan dan mencoba untuk menimbulkan perasaan terkait dalam tubuh sendiri.

d. Biofeedback

Di sini seseorang belajar bagaimana mengenali dan mengelola respons fisiologis melalui umpan balik yang biasanya difasilitasi oleh penggunaan instrumentasi.

e. Hipnoterapi

Melibatkan menciptakan keadaan di mana seorang individu dapat disugesti. Hal ini sering digunakan untuk menciptakan perasaan relaksasi dan akibatnya termasuk di sini (Sj, EFabbrocini, G., Napolitano, M., Megna, M., Balato, N., \& Patruno et al., 2009).

2. Intervensi Perilaku

a. Terapi perilaku melibatkan penerapan teori perilaku untuk merubah perilaku.

b. Pembalikan kebiasaan adalah bentuk intervensi perilaku yang digunakan untuk memodifikasi goresan yang tidak membantu. 
c. Bentuk lain dari intervensi perilaku yaitu penggunaan sistem manajemen kontingensi (misalnya, melalui penggunaan sistematis grafik untuk mencatat dan menghargai kemajuan) (Sj, EFabbrocini, G., Napolitano, M., Megna, M., Balato, N., \& Patruno et al., 2009).

3. Terapi psikologis yang berfokus pada proses internal

Terapi yang secara luas disebut sebagai 'terapi berbicara', dan ini umumnya dikaitkan dengan peningkatan wawasan dan tidak melibatkan penggunaan teknik khusus untuk mengubah proses psikologis internal, perilaku eksternal, dan gaya koping.

a. Terapi perilaku kognitif mengambil perspektif biopsikososial yang melibatkan promosi pendekatan empiris, yaitu membantu individu dalam memahami hubungan antara pikiran, proses berpikir, dan perilaku mereka. Selain menggambar pada teori kognitif, itu juga mengacu pada teori dan teknik perilaku. Ini berfokus pada masalah dan dapat menggunakan berbagai teknik untuk meningkatkan kesadaran - dan untuk mengubah pemikiran tertentu - proses kognitif, perasaan, atau perilaku dan untuk meningkatkan strategi koping.

b. Konseling: biasanya pendekatan non-directive, non-judgemental, empati, dan suportif, yang memungkinkan individu untuk mengatasi masalah atau keadaan batin mereka secara lebih efektif.

c. Terapi keluarga: memandang keluarga, bukan anggota individu, sebagai unit yang membutuhkan bantuan. Semua jenis terapi keluarga melibatkan mendorong anggota keluarga untuk berbicara satu sama lain, memeriksa ketidakfleksibelan, aturan dan keyakinan keluarga, dengan fokus pada hubungan dalam keluarga dan hubungan antara keluarga dan agen eksternal, mis. kesehatan, pendidikan, pekerjaan, dan pelayanan sosial.

d. Pendekatan psikodinamik menekankan pada motif dan dorongan bawah sadar. Tujuan terapi adalah mengenali pertahanan yang tidak membantu dan menghubungkannya dengan konflik yang mendasarinya. Ini mungkin termasuk fokus pada masa lalu dan memanfaatkan hubungan antara pasien dan terapis untuk memahami asal dan pemeliharaan kesusahan

(Sj, EFabbrocini, G., Napolitano, M., Megna, M., Balato, N., \& Patruno et al., 2009).

Selain pengobatan yang disebutkan di atas, jika pasien mengalami gejala gangguan depresi dan gangguan cemas perlu diberikan perlu diberikan pengobatan psikofarmaka (Kementerian Kesehatan RI, 2015).

\begin{tabular}{|l|c|l|}
\hline \multicolumn{1}{|c|}{ Nama Obat } & $\begin{array}{c}\text { Dosis } \\
\text { Harian (mg) }\end{array}$ & \multicolumn{1}{c|}{ Efek Samping } \\
\hline $\begin{array}{l}\text { SNRI } \\
\text { Duloksetin } \\
\text { Venlafaksin }\end{array}$ & $\begin{array}{c}40-60 \\
150-375\end{array}$ & $\begin{array}{l}\text { mengantuk, kenaikan BB, } \\
\text { hipertensi,gangguan saluran cerna }\end{array}$ \\
\hline $\begin{array}{l}\text { RIMA } \\
\text { Moklobemid }\end{array}$ & $150-300$ & $\begin{array}{l}\text { pusing, sakit kepala, mual, } \\
\text { berkeringat, mulut kering, mata } \\
\text { kabur }\end{array}$ \\
\hline $\begin{array}{l}\text { NaSSA } \\
\text { Mirtazapin }\end{array}$ & $15-45$ & somnolen, mual \\
\hline $\begin{array}{l}\text { SSRE } \\
\text { Tianeptin }\end{array}$ & $12.5-37.5$ & $\begin{array}{l}\text { somnolen, mual, gangguan } \\
\text { kardiovaskular }\end{array}$ \\
\hline $\begin{array}{l}\text { Melatonin Agonis } \\
\text { Agomelatin }\end{array}$ & $25-50$ & sakit kepala \\
\hline
\end{tabular}


Ninda Nurkhalifah, Ridha Sasmitha Ajiningrum, Ilma Fahira Basyir, Genta Faesal Atsani, Zanetha Mauly Ilawanda

Jenis Obat Antidepresan, Dosis dan Efek Samping
\begin{tabular}{|l|c|l|}
\hline \multicolumn{1}{|c|}{ Nama Obat } & $\begin{array}{c}\text { Dosis } \\
\text { Harian (mg) }\end{array}$ & \multicolumn{1}{c|}{ Efek Samping } \\
\hline SSRI & $20-60$ & semua SSRI bisa menimbulkan \\
Escitalopram & $10-40$ & insomnia, agitasi, sedasi, \\
Fluoksetin & $50-150$ & gangguan saluran cerna dan \\
Sertralin & $150-300$ & disfungsi seksual \\
Fluvoksamin & & \\
Trisiklik/Tetrasiklik & $75-300$ & antikolinergik \\
Amitriptilin & $100-225$ & \\
Maprotilin & $75-300$ & \\
Imipramin & & \\
\hline
\end{tabular}

\begin{tabular}{|c|c|c|c|}
\hline \multicolumn{4}{|c|}{ Rekomendasi Farmakoterapi untuk Gangguan Panik } \\
\hline & Nama Obat & \begin{tabular}{|c} 
Dosis \\
(mg/hari)
\end{tabular} & Efek Samping \\
\hline \multirow[t]{4}{*}{ Lini pertama } & escitalopram, & $5-20$ & \multirow{4}{*}{$\begin{array}{l}\text { Gangguan pencernaan, mual, } \\
\text { muntah diare, konstipasi }\end{array}$} \\
\hline & fluoksetin, & $10-20$ & \\
\hline & sertralin, & $25-200$ & \\
\hline & venlafaksin-XR & $75-250$ & \\
\hline \multirow[t]{5}{*}{ Lini kedua } & klomipramin, & $25-250$ & \multirow[t]{2}{*}{ antikolinergik } \\
\hline & imipramin, & $50-300$ & \\
\hline & mirtazapin, & $15-45$ & antihistamin \\
\hline & Alprazolam & $2-6$ & \multirow[t]{2}{*}{ sedasi } \\
\hline & \begin{tabular}{|l|} 
adjunctive \\
klonazepam
\end{tabular} & $1-3$ & \\
\hline \multirow[t]{4}{*}{ Lini ketiga } & divalproat & $250-1500$ & $\begin{array}{l}\text { Sedasi, somnolens, } \\
\text { peningkatan berat badan, } \\
\text { system pencernaan }\end{array}$ \\
\hline & gabapentin & $300-1200$ & Somnolens, sedasi \\
\hline & $\begin{array}{l}\text { adjunctive } \\
\text { olanzapin }\end{array}$ & $5-12.5$ & Peningkatan berat badan \\
\hline & risperidon & $0.5-1$ & Sindrom ekstrapiramidal \\
\hline
\end{tabular}

Gambar 2. Jenis Psikofarmaka Gangguan Cemas dan Depresi

\section{Kesimpulan}

Dermatitis Atopik (DA) adalah penyakit kulit inflamasi yang umum, kronis, kambuhan, yang biasanya menyerang pada bayi (namun juga dapat terjadi pada masa dewasa). Dermatitis atopik terjadi sekitar $10 \%$ hingga $30 \%$ pada anak-anak dan $2 \%$ hingga $10 \%$ pada orang dewasa di negara maju. Etiologi dari DA terdiri dari faktor genetik dan lingkungan yang menyebabkan kelainan pada epidermis dan sistem kekebalan tubuh. Individu dengan eksim atopik lebih mungkin mengalami depresi dan kecemasan karena efek gatal dan ketidaknyamanan, cacat, dan stigmatisasi sosial yang dirasakan. Selain itu, kurang tidur akibat rasa gatal pada malam hari dapat meningkatkan resiko terjadinya gangguan jiwa. Hal tersebut menyebabkan individu dengan DA memiliki kualitas hidup yang lebih rendah dan tingkat stres yang lebih tinggi daripada individu yang sehat. 


\section{BIBLIOGRAFI}

Avena-Woods, C. (2017). Atopic Dermatitis: Focusing on the Patient Care Strategy in the Managed Care. Supplements and Featured Publications. Retrieved June 12, 2021, from https://www.ajmc.com/view/overview-of-atopic-dermatitis-article

Benea, V. et al. (2001) 'Stress and Atopic Dermatitis', (12), pp. 1-3. Google Scholar

Indrastiti, R., Kurniati, I. D. and Saputri, E. O. (2016) 'Faktor yang Mempengaruhi Kualitas Hidup Pasien Dermatitis Atopik Factors that Influence The Level of Quality of Life Atopic Dermatitis Patients', unimus, pp. 1-10. Google Scholar

Kage, P. and Treudler, R. (2020) 'Atopic dermatitis and psychosocial comorbidities', pp. 93-102. doi: 10.1111/ddg.14029. Google Scholar

Kauppi, S. et al. (2019a) 'Adult Patients with Atopic Eczema have a High Burden of Psychiatric', pp. 647-651. doi: 10.2340/00015555-3165. Google Scholar

Kauppi, S. et al. (2019b) 'Adult patients with atopic eczema have a high burden of psychiatric disease: A finnish nationwide registry study', Acta DermatoVenereologica, 99(7), pp. 647-651. Google Scholar.

Kementerian Kesehatan RI (2015) 'Keputusan Menteri Kesehatan Republik Indonesia Pedoman Nasional Pelayanan Kedokteran Jiwa Dengan', Nomor HK.02.02/MENKES/73/2015, 151, pp. 10-17. Google Scholar

Lifschitz, C. (2015a) 'Patients with skin diseases experience a wide range of symptoms ranging from trivial problems to major The Impact of Atopic Dermatitis on Quality of Life The Impact of Atopic Dermatitis on', 66(suppl 1), pp. 34-40. Google Scholar

Lifschitz, C. (2015b) 'The impact of atopic dermatitis on quality of life', Annals of Nutrition and Metabolism, 66(suppl 1), pp. 34-40. doi: 10.1159/000370226. Google Scholar

Oh, S. H. et al. (2010) 'Association of Stress with Symptoms of Atopic Dermatitis A', (November). doi: 10.2340/00015555-0933. Google Scholar

Osman, O. T. et al. (2011) 'The psychiatric aspects of skin disorders', (October 2016). doi: 10.1586/edm.11.10. Google Scholar

Schonmann, Y. et al. (2020) 'Atopic Eczema in Adulthood and Risk of Depression and Anxiety: A Population-Based Cohort Study', Journal of Allergy and Clinical Immunology: In Practice, 8(1), pp. 248-257.e16. Google Scholar

Schonmann, Y. and Mansfield, K. E. (2019) 'Atopic Eczema in Adulthood and Risk of Depression and Anxiety: A Population-Based Cohort Study'. doi: 10.1016/j.jaip.2019.08.030. Google Scholar

Sj, EFabbrocini, G., Napolitano, M., Megna, M., Balato, N., \& Patruno, C. (2018). T. of A. D. with B. D. D. and T. https://doi. org/10. 1007/s1355.-018-0258-xrsser et al. (2009) 
Ninda Nurkhalifah, Ridha Sasmitha Ajiningrum, Ilma Fahira Basyir, Genta Faesal Atsani, Zanetha Mauly Ilawanda

'Psychological and FChan-Yeung, M., Dimich-Ward, H., \& Becker, A. (2007). Atopy in early life and efChan-Yeung, M., Dimich-Ward, H., \& Becker, A. (2007). Atopy in early life and effect of a primary prevention program for asthma in a highrisk cohort. Journ', The Cochrane Library, (1).

Stander, S. (2021) 'Atopic Dermatitis', The New England Journal of Medicine. doi: 10.1056/NEJMra2023911. Google Scholar

Thorsti, A., Rønnstad, M. and Halling-overgaard, A. (2018) Association of atopic dermatitis with depression, anxiety, and suicidal ideation in children and adults : A systematic review and meta-analysis, Journal of American Dermatology. Elsevier Inc. Google Scholar

Yaghmaie, P., Koudelka, C. and Simpson, E. (2013) 'Mental Health Comorbidity in Atopic Dermatitis', 131(2), pp. 428-433. Google Scholar

Yaghmaie, P., Koudelka, C. W. and Simpson, E. L. (2013) 'Mental health comorbidity in patients with atopic dermatitis', Journal of Allergy and Clinical Immunology. Elsevier Ltd, 131(2), pp. 428-433. Google Scholar

\section{First publication right:}

Jurnal Syntax Fusion: Jurnal Nasional Indonesia

This article is licensed under:

(c) (†) () 